Welcome to the September 2017 issue of CERL News. In light of the current political and social climate, many libraries and librarians are renewing their commitment to core professional values such as diversity and inclusion. At Portland State University, librarians are an integral part of teams working to support a culturally responsive and inclusive curriculum. Kimberly Pendell and Robert Schroeder write about the project in "Librarians as campus partners."

In this month's Internet Resources column, Jennifer Kaari provides an overview of digital collections and primary sources focused on "Social activism in the United States." While the list is by no means comprehensive, it provides an excellent starting point for information on several social justice topics.

The start of the new academic year means a return to library and campus-wide meetings. Kate Dohe and Erin Pappas share ways in which lessons from improv comedy can inform affirmative collaborations in their article "The many flavors of 'yes,'” and Mark Bieraugel of Cal Poly discusses his use of Liberating Structures to help attendees "Never be bored at a meeting again!"
In this issue's Scholarly Communication column, Devin Soper reflects "On passing an open access policy at Florida State University," providing a roadmap for other libraries beginning a similar process, while Douglas Black of Middlebury College writes about his experiences as "An accidental datahound" in this month's The Way I See It essay.

The University of Illinois-Chicago Library recently underwent a reorganization, creating a new technical services collection management unit. Gwen M. Gregory writes about the project in her article "For the duration."

This month we look back at the 2017 ALA Annual Conference in Chicago with our annual roundup of ACRL programs and Board of Directors actions. Many thanks to all the reporters who volunteered to write program summaries.

Make sure to check out the other features and departments this month, including the call for nominations for ACRL's 2018 awards program and a look at the September issue of College $\&$ Research Libraries from editor Wendi Kaspar.

—David Free, editor-in-chief, dfree@ala.org

\title{
Accessible archives
}

\section{THE SPREAD OF WOMEN'S SUFFRAGE IN THE WEST}

Women's suffrage flourished in the West where women received early voting rights.

Follow the growth of this significant political force in our new titles:

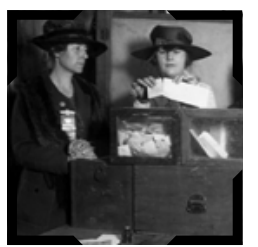

The NeW Citizen. Seattle, WA 1909-1912

WESTERN WOMAN VOTER. SEATTLE, WA 1911-1913

But not all women favored universal suffrage. They espoused their opposition in publications such as:

The Remonstrance: An Anti-Suffrage Periodical. Boston, MA 1890-1913

ALSO AVAILABLE: THE LILY, NATIONAL CITIZEN AND BALLOT BOX, AND THE REVOLUTION.

For a Free Trial and Pre-pub pricing contact our exclusive sales and marketing agent: iris.hanney@unlimitedpriorities.com or call 239-549-2384. 